\title{
Undiscovered Gas Resources in the Alum Shale, Denmark, 2013
}

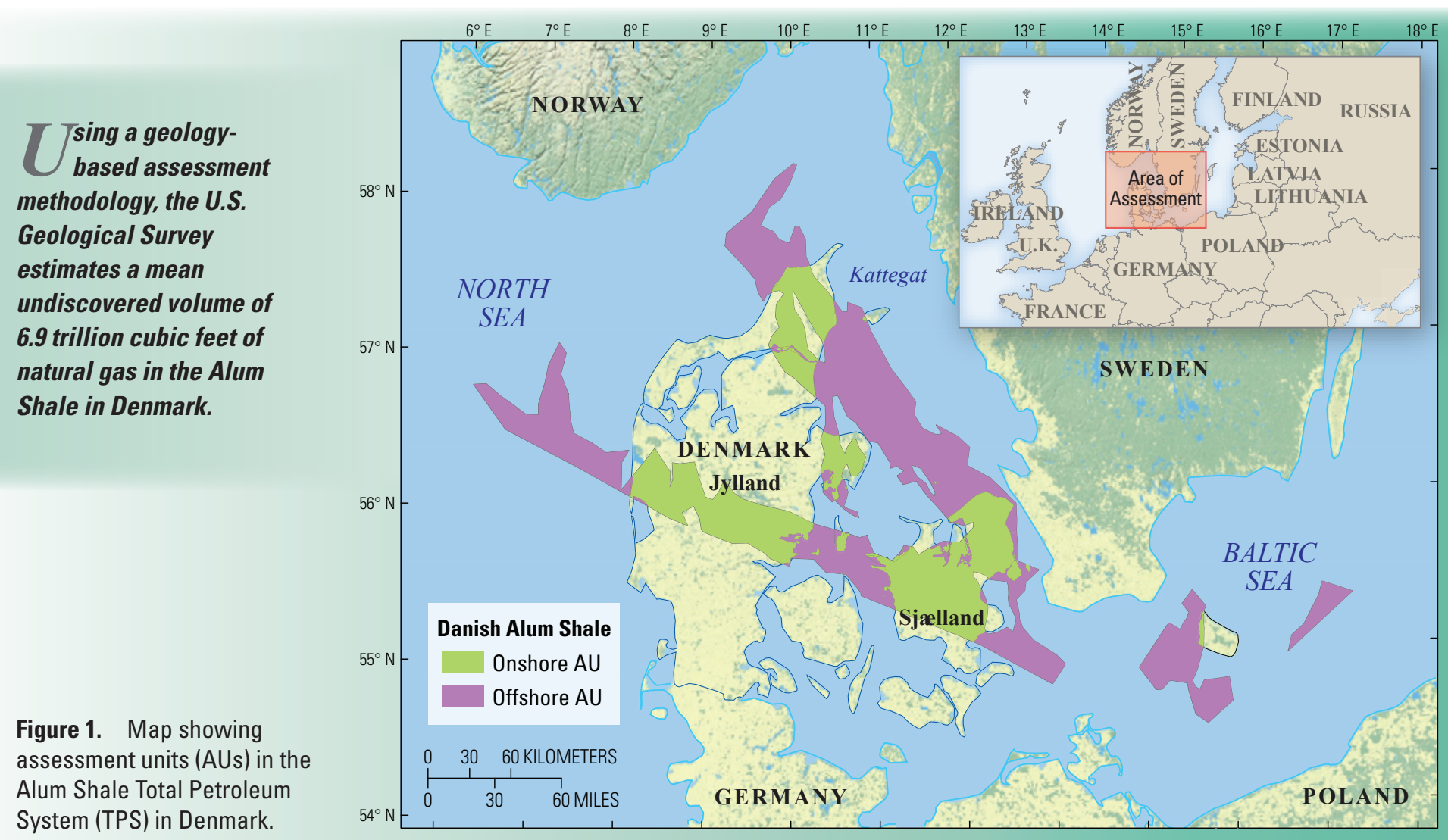

\section{Introduction}

The U.S. Geological Survey (USGS) recently completed a geology-based assessment of continuous gas resources of the lower Paleozoic shales in Denmark (fig. 1). Stratigraphically equivalent strata have been tested by several wells in Scania (southern Sweden), with largely negative results. However, Paleozoic shales in Jylland and on Sjælland have not been tested by drilling and various lines of geological evidence suggest that significant natural gas resources may be preserved in certain tilted fault blocks in the subsurface of Denmark.

\section{Geology of Potentially Productive Danish Shales}

Organic-carbon-rich rocks ranging in age from Middle Cambrian to Early Cretaceous are present in the subsurface of Denmark. Mesozoic shales are thermally immature in all but the deepest parts of the Norwegian-Danish Basin, where some Jurassic strata associated with salt structures may be marginally mature with respect to oil (Petersen and others, 2008). The Mesozoic shales are, therefore, not likely to contain significant petroleum resources and are not considered further in this study.

Lower Paleozoic black shales of Cambrian, Ordovician, and Silurian age may be potentially productive. Of these, the Cambrian to Lower Ordovician Alum Shale is the thickest and richest (Schovsbo and others, 2011); it is the principal subject of the assessment.

The Alum Shale was deposited in an epicontinental sea that covered the passive margins of the Baltic craton from Middle Cambrian into Early Ordovician time. During maximum flooding in the Early Ordovician, organic-rich mudstones accumulated over an area of more than
1,000,000 square kilometers $\left(\mathrm{km}^{2}\right)$

(Nielsen and Schovsbo, 2011).

In northern Denmark the Alum Shale can exceed 180 meters $(\mathrm{m})$ in thickness (Nielsen and Schovsbo, 2007). Southward it thins to less than $20 \mathrm{~m}$, probably as a result of syndepositional uplift and erosion near the margins of the Baltic craton. Consequently Paleozoic shales are not considered to be potentially productive south of the Ringkøbing-Fyn High in Denmark.

In Late Ordovician and Silurian time, before the Caledonian tectonic collision, the Baltic passive margins were transformed into foreland basins as the Laurentian and Avalonian cratons approached Baltica (Schovsbo, 2003). Thick successions of sedimentary strata buried the Alum and other lower Paleozoic shales to depths of 4 to 5 kilometers $(\mathrm{km})$, bringing them to thermal maturity for oil and then for 
gas (greater than 2-percent graptolite reflectance; 1.6-percent $\mathrm{R}_{\mathrm{o}}$, vitrinitereflectance-equivalent maturity) in most areas (Buchardt and others, 1997; Petersen and others, 2013). Given the thickness and richness of the shales, this burial history almost certainly resulted in generation of large volumes of hydrocarbons.

Regional uplift, normal faulting, and erosion in the Early Devonian (Mogensen and Korstgård, 2003) affected the lower Paleozoic shales throughout Denmark and adjacent areas, bringing the shales to depths of less than $1,000 \mathrm{~m}$ in some areas. Discontinuous subsidence was renewed in the Permo-Triassic, Early Cretaceous, and Paleogene, followed by uplift in the late Neogene and by glacial erosion in the Pleistocene.

Consequently, the Paleozoic shales occur today as remnants in tilted fault blocks, which include strata as young as earliest Permian. The fault blocks are preserved beneath the Variscan unconformity and are overlain by rocks of the Zechstein Formation and younger strata (fig. 2).

This complicated geological history of burial, uplift, and erosion is known to have caused depressurization and gas loss in Scania, where some areas have been uplifted to shallow depths (Pool and others, 2012). Similar gas loss is believed to account for the absence of producible hydrocarbons in a well in the Kattegat (fig.1). Uplift to shallow depths and depressurization during the late Paleozoic pose the greatest risk to natural gas retention and resource potential in the Alum Shale of Denmark.
In Denmark, the Alum Shale comprises three members that differ in composition, texture, and distribution. The Middle Cambrian lower member was deposited in an oxygenated environment and has the lowest organic matter content of the three. The Upper Cambrian (Furongian) middle member accumulated under conditions of oxygen depletion. The Furongian is the most organic-rich and is the most likely source-rock system reservoir considered in this assessment (fig. 3). It is thickest in northern Denmark. The upper member, of Early Ordovician age, has concentrations of organic matter intermediate between the Middle Cambrian and Furongian shales.

\section{Geological Model for Assessment}

In Denmark, large volumes of oil and then gas were generated from organic-rich lower Paleozoic shales during deep burial in pre-Caledonian foreland basins on the margins of the Baltic craton. In most areas the burial history resulted in temperature exposures sufficient to bring organic matter to a maturation rank of dry gas, cracking previously formed oil. As a result, significant volumes of shale oil are not expected in Denmark.

Although free hydrocarbons were lost in areas subject to intensive uplift and erosion during the Devonian, significant quantities of natural gas may have been preserved in certain areas. Subsidence was renewed in the Permian and Triassic and maximum reburial probably occurred in Cretaceous to early Paleogene time. Modeling suggests that the thermal rank reached during the early Paleozoic was never exceeded during the reburial phases. Therefore, a second episode of gas generation is considered unlikely except in the deeper parts of the Danish-Norwegian Basin where the present-day depth of the lower Paleozoic exceeds $7 \mathrm{~km}$ (Lassen and Thybo, 2012). Nevertheless, because of sparse data and modeling uncertainty, the possibility exists that lower Paleozoic shales have retained hydrocarbon-generating potential throughout the Paleozoic and may have generated additional hydrocarbons during Mesozoic and Cenozoic time in some areas.

\section{Assessment Units}

Two separate continuous-type assessment units (AUs), one onshore and one offshore, were defined. Each consists of Paleozoic shales preserved in tilted fault blocks currently at depths between 1.5 and $7 \mathrm{~km}$ in the subsurface in Denmark. The fault blocks are known, on the basis of seismic data and sparse well control, to occur in northern Jylland, on Sjælland, and in adjacent offshore areas in the Baltic Sea, the Kattegat, and the North Sea (fig. 1). Within these two assessment units, "sweet spots" were defined as those fault blocks that contain Furongian Alum Shale and thick post-Alum Paleozoic strata, indicating less intense exposure to late Paleozoic uplift and erosion and greater probability of gas retention.
Figure 2. Schematic cross section of the geology and stratigraphy in part of northern Jylland, Denmark, showing the geological situation of lower Paleozoic shales, including the prospective Alum Shale, in a tilted fault block (vertical exaggeration $\sim$ x2). (Courtesy of Geological Survey of Denmark and Greenland.)

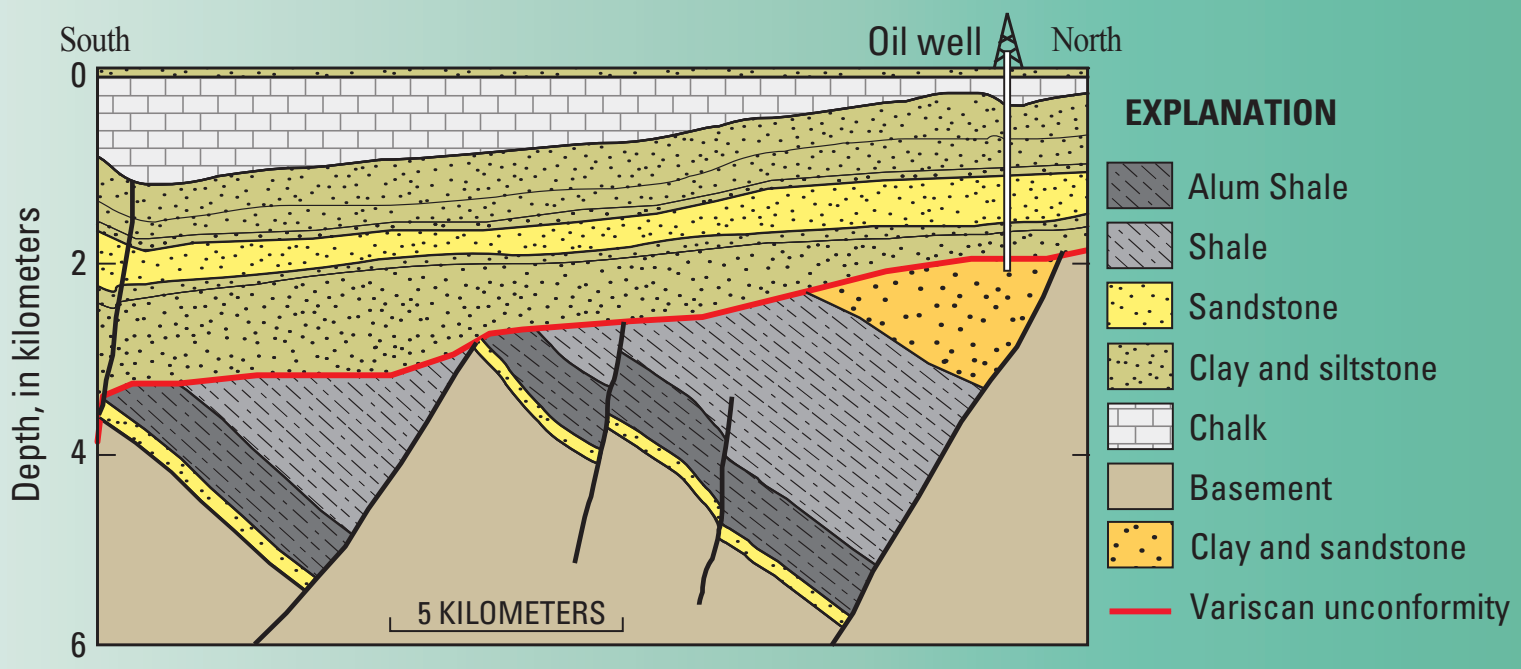


Table 1. Key assessment input data for continuous assessment units in the Alum Shale Total Petroleum System in Denmark.

[EUR, estimated ultimate recovery per well; BCFG, billion cubic feet of gas; AU, assessment unit. The average EUR input is the minimum, median maximum, and calculated mean. \%, percent]

\begin{tabular}{|c|c|c|c|c|c|c|c|c|}
\hline \multirow[b]{2}{*}{ Assessment input data } & \multicolumn{4}{|c|}{ Danish Alum Shale Onshore AU } & \multicolumn{4}{|c|}{ Danish Alum Shale Offshore AU } \\
\hline & Minimum & Mode & Maximum & $\begin{array}{c}\text { Calculated } \\
\text { mean }\end{array}$ & Minimum & Mode & Maximum & $\begin{array}{c}\text { Calculated } \\
\text { mean }\end{array}$ \\
\hline Potential production area of AU (acres) & $3,000,000$ & $3,225,000$ & $4,000,000$ & $3,408,333$ & $4,700,000$ & $5,042,000$ & $6,250,000$ & $5,330,667$ \\
\hline Average drainage area of wells (acres) & 120 & 160 & 200 & 160 & 120 & 160 & 200 & 160 \\
\hline Percentage of AU in sweet spots (\%) & 10 & 20 & 40 & 23 & 15 & 30 & 60 & 35 \\
\hline \multicolumn{9}{|c|}{ Input data for geologic sweet spots } \\
\hline Average EUR (BCFG, gas) & 0.1 & 0.45 & 1.3 & 0.492 & 0.1 & 0.45 & 1.3 & 0.492 \\
\hline Success ratios $(\%)$ & 10 & 50 & 90 & 50 & 10 & 50 & 90 & 50 \\
\hline \multicolumn{9}{|c|}{ Input data for geologic non-sweet spots } \\
\hline Average EUR (BCFG, gas) & 0.1 & 0.2 & 1 & 0.245 & 0.1 & 0.2 & 1 & 0.245 \\
\hline Success ratios (\%) & 10 & 40 & 70 & 40 & 10 & 40 & 70 & 40 \\
\hline
\end{tabular}

\section{Resource Summary}

The USGS assessed

technically recoverable continuous (unconventional) resources in two AUs defined in the Alum Shale resulting in a total estimated mean of 6,935 billion cubic feet of gas (BCFG) (table 2). This includes estimated gas resources of 0 to 4,848 BCFG in the Onshore Continuous Gas AU (mean = 2,509 $\mathrm{BCFG}$ ) and 0 to $8,492 \mathrm{BCFG}$ in the Offshore Gas AU (mean = 4,426 $\mathrm{BCFG).} \mathrm{Natural} \mathrm{gas} \mathrm{liquids} \mathrm{were}$ assessed to be negligible.

\section{Acknowledgments}

Although the assessment methodology, numerical input, risking structure, and quantitative estimates reported here are the exclusive product of the USGS, the geological foundation of the assessment relies on concepts, data, and interpretations provided by the Geological Survey of Denmark and Greenland (GEUS). The collaboration of Niels H. Schovsbo, of GEUS, is specifically and gratefully acknowledged. Janet K. Pitman, USGS emerita, developed the burial history models used for interpretation of resource potential.

\section{References Cited}

Buchardt, B., Nielsen, A.T., Schovsbo, N.H., 1997, Alun Skiferen i

Skandinavien: Geologisk Tidsskrift, v. 3, p. 1-30.
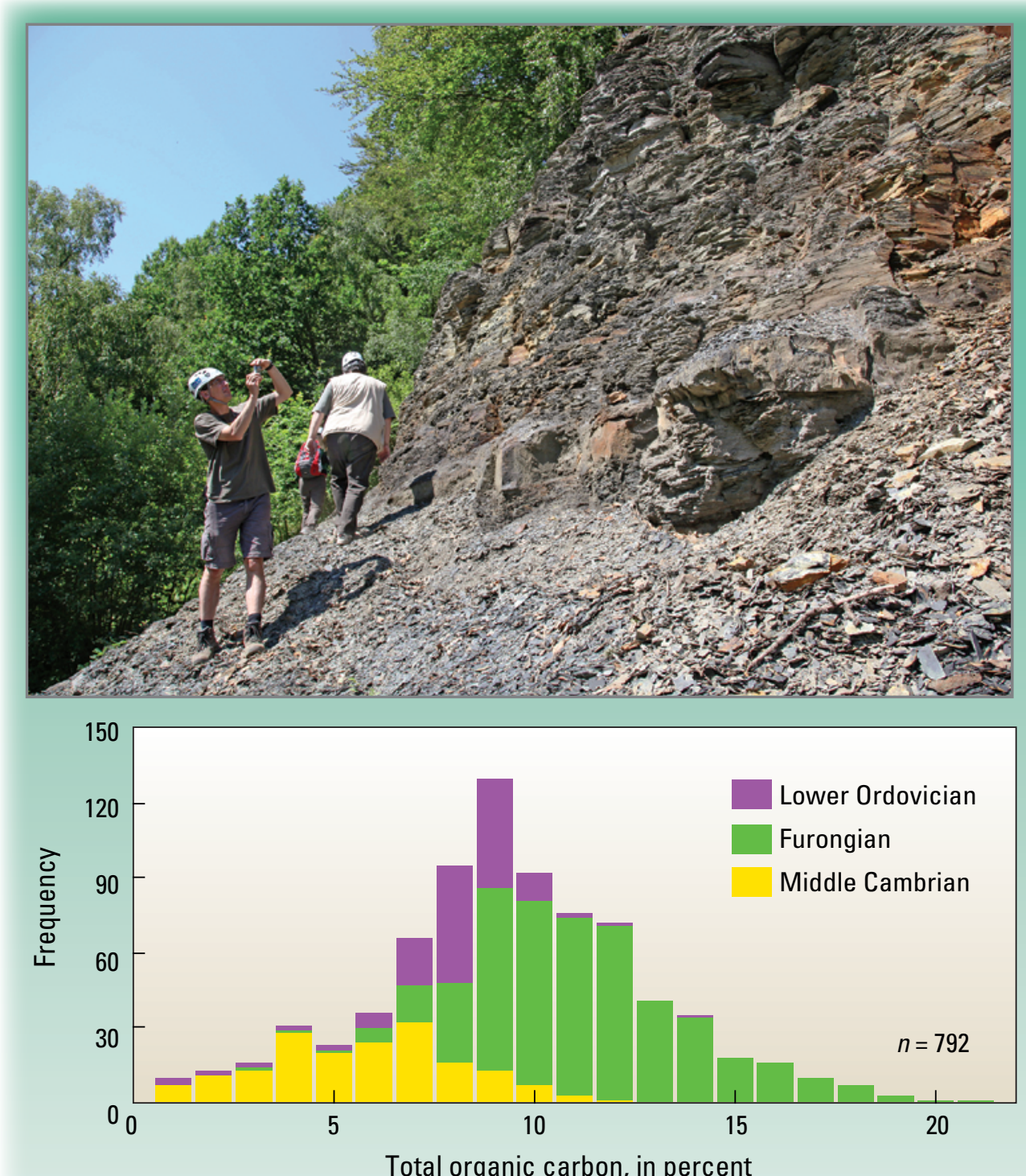

Figure 3. Photograph of an Alum Shale outcrop with inset graph showing the distribution of total organic carbon (TOC) in three gas-mature members of the Alum Shale in Denmark. (Geological Survey of Denmark and Greenland photograph; graph modified from Schovsbo and others, 2011.) 
Table 2. Alum Shale, Denmark, assessment results.

[BCFG, billion cubic feet of gas. MMBNGL, million barrels of natural gas liquids. Results shown are fully risked estimates. F95 represents a 95-percent chance of at least the amount tabulated; other fractiles are defined similarly. Fractiles are additive only under an assumption of perfect positive correlation. TPS, total petroleum system; AU, assessment unit; NGL, natural gas liquids]

\begin{tabular}{|c|c|c|c|c|c|c|c|c|c|c|}
\hline \multirow{3}{*}{$\begin{array}{c}\text { Provinces, } \\
\text { Total petroleum systems (TPS), } \\
\text { and Assessment Units (AU) }\end{array}$} & \multirow{3}{*}{$\begin{array}{c}\text { AU } \\
\text { probability }\end{array}$} & \multirow{3}{*}{$\begin{array}{c}\text { Accumulation } \\
\text { type }\end{array}$} & \multicolumn{8}{|c|}{ Total undiscovered resources } \\
\hline & & & \multicolumn{4}{|c|}{ Gas (BCFG) } & \multicolumn{4}{|c|}{ NGL (MMBNGL) } \\
\hline & & & F95 & F50 & F5 & Mean & F95 & F50 & F5 & Mean \\
\hline \multicolumn{11}{|c|}{ Alum Shale TPS } \\
\hline Danish Alum Shale Onshore AU & 0.9 & Gas & 0 & 2,433 & 4,848 & 2,509 & 0 & 0 & 0 & 0 \\
\hline Danish Alum Shale Offshore AU & 0.9 & Gas & 0 & 4,328 & 8,492 & 4,426 & 0 & 0 & 0 & 0 \\
\hline Total unconventional resources & & & 0 & 6,761 & 13,340 & 6,935 & 0 & 0 & 0 & 0 \\
\hline
\end{tabular}

Lassen, A., Thybo, H., 2012,Neoproterozoic and Palaeozoic evolution of SW Scandinavia based on integrated seismic interpretation: Precambrian Research,v. 204-205, p. 75-104.

Mogensen, T.E., Korstgård, J.A., 2003, Triassic and Jurassic transtension along part of the Sorgenfrei-Tornquist Zone, in the Danish Kattegat, in Ineson, J.R, Surlyk, F.,eds., The Jurassic of Denmark and Greenland: Geological Survey of Denmark and Greenland Bulletin 1, p. 439-458.

Nielsen, A.T., Schovsbo, N.H., 2007, Cambrian to basal Ordovician lithostratigraphy of southern Scandinavia: Bulletin of the Geological Society of Denmark 53, p. 39-85.

Nielsen, A.T., Schovsbo, N.H., 2011, The Lower Cambrian of ScandinaviaDepositional environment, sequence stratigraphy and palaeogeography: Earth Science Reviews, v. 107, p. 207-310.

Petersen, H.I., Nielsen, L.H., BojesenKoefoed, J.A., Mathiesen, A., Kristensen, L., Dalhoff, F., 2008, Evaluation of the quality, thermal maturity and distribution of potential source rocks in the Danish part of the Norwegian-Danish Basin: Geological Survey of Denmark and Greenland Bulletin 16, p. 1-66.
Petersen, H.I., Schovsbo, N.H., Nielsen, A.T., 2013, Reflectance measurements of zooclasts and solid bitumen in Lower Palaeozoic shales, southern Scandinavia-Correlation to vitrinite reflectance: International Journal of Coal Petrology, v. 114, p. 1-18.

Pool, W., Geluk, M., Abels, J., Tiley, G., 2012, Assessment of an unusual European Shale Gas play-The Cambro-Ordovician Alum Shale, southern Sweden: Proceedings of the Society of Petroleum Engineers/European Association of Geoscientists and Engineers Unconventional Resources Conference, Vienna, Austria, March 20-22, 2012, 152339.

Schovsbo, N.H., 2003, Geochemical composition and provenance of Lower Palaeozoic shales deposited at the margins of Baltica: Bulletin of the Geological Society of Denmark, v. 50, p. 11-27.

Schovsbo, N.H., Nielsen, A.T., Klitten, K., Mathiesen, A., Rasmussen, P., 2011, Shale gas investigations in Denmark-Lower Palaeozoic shales on Bornholm: Geological Survey of Denmark and Greenland Bulletin 23, p. $9-12$.
Alum Shale Assessment Team: Donald L. Gautier (Task Leader), Ronald R. Charpentier, Stephanie B. Gaswirth, Timothy R. Klett, Janet K. Pitman, Christopher J. Schenk, Marilyn E. Tennyson, and Katherine J. Whidden

Edited by James W. Hendley II Design by Jeanne S. DiLeo

\section{Additional Information}

Supporting geological studies of the Alum Shale and methodology used in the assessment are available

from the Geological Survey of

Denmark and Greenland (http://www.geus.dk/) and from the USGS Energy Resources Program

Web site (http://energy.usgs.gov)

or contact: Christopher J. Schenk (schenk@usgs.gov)

This Fact Sheet and any updates to it are available online at: http://pubs.usgs.gov/fs/2013/3103/ 